\title{
Pelatihan dan Pendampingan Penyusunan Cost Of Goods Sold untuk Menentukan Harga Jual Produk pada Usaha Tenun di Kecamatan Sidemen Kabupaten Karangasem
}

\section{Gusti Ayu Purnamawati1 ${ }^{*}$, Gede Adi Yuniarta², I Putu Gede Diatmika ${ }^{3}$}

1 Jurusan Akuntansi Program Diploma III

A R T I C L E I N F 0

Article history:

Received 20 Oktober

2017

Received in revised

form

4 November 2017

Accepted 15 Januari

2018

Available 20 Februari

2018

Kata Kunci:

traditional weavers, harga jual produk,

tenun ikat.

Keywords:

ikat weaving,

product selling price, traditional weavers
A B S T R A K

Secara umum program pengabdian masyarakat ini bertujuan memberikan pelatihan dan pendampingan penyusunan Cost Of Goods Sold (Harga Pokok Produksi) untuk menentukan harga jual produk pada usaha tenun ikat (Traditional Weavers) di Kecamatan Sidemen Kabupaten Karangasem. Metode yang digunakan dalam kegiatan ini adalah metode praktik langsung. Adapun materi yang diberikan selama pelatihan dan pendampingan meliputi : (1) pentingnya pembukuan dan keuntungan penggunaannya dalam menjalankan usaha, (2) cara menghitung harga pokok produksi untuk produk yang dihasilkan, dan (3) informasi biaya yang diperlukan dalam pengendalian biaya produksi. Hasil kegiatan menunjukkan bahwa: setelah kegiatan pelatihan dilakukan, keterampilan masyarakat perajin mulai mengalami peningkatan sebesar $80 \%$. Sebagian besar sudah dapat menghitung harga pokok produksi dan menentukan harga jual dengan benar

\section{A B S T R A C T}

In general, community service program aims to provide training and assistance for the preparation of Cost Of Goods Sold (Cost of Production) to Determine the Price of Selling Products on Traditional Weavers Business in Sidemen District, Karangasem Regency. The method used in this activity is the direct practice method. The material provided during the training and assistance includes: (1) the importance of bookkeeping and the benefits of its use in running the business; (2) how to calculate the cost of production for the product; (3) cost information required in controlling production costs. The result of the activity shows that: after the training activity is done, the craftsman community's skill starts to increase by $80 \%$. Most have been able to calculate the cost of production and determine the selling price correctly.

Copyright (C) Universitas Pendidikan Ganesha. All rights reserved.

Corresponding author.

E-mail addresses: ayupurnama07@yahoo.com (I Gusti Ayu Purnamawati), 


\section{Pendahuluan}

Di era global seperti saat ini perusahaan diharuskan untuk meningkatkan efisiensi serta efektivitas proses produksinya agar dapat meningkatkan daya saingnya. Persaingan di dunia global saat ini tidak hanya menuntut perusahaan untuk memproduksi barang sebanyak-banyaknya namun bagaimana produsen barang tersebut tepat dalam metode perhitungan harga produksinya. Apabila perhitungan harga pokok produksi kurang tepat dalam perhitungannya, maka yang akan terjadi adalah harga barang produksi terlalu mahal sehingga produk tidak diminati konsumen. Sebaliknya apabila harga terlalu rendah memang akan menarik minat konsumen untuk membeli produk hasil produksi perusahaan. Hal ini menyebabkan hasil penjualan tidak dapat menutup biaya produksi apabila keadaan ini terus berlanjut dan dapat menyebabkan kebangkrutan perusahaan.

Penentuan harga pokok produksi menurut Mulyadi (2003:40) dapat dilakukan dengan menggunakan metode full costing, variabel costing atau dengan sistem activity based costing, namun untuk metode full costing atau konvensional terjadi banyak sekali distorsi dalam penentuan harganya karena sistem pembebanan biaya tidak diperhitungkan secara detail. Hal ini memerlukan sistem perhitungan yang lebih akurat yaitu sistem activity based costing seperti yang dikemukakan oleh Slamet (2007:103) merupakan sistem pembebanan biaya dengan cara pertama kali menelusuri biaya aktivitas dan kemudian ke produk. Produksi kain endek sutra warna alam Bali tersebar di setiap daerah, seperti di Klungkung, Gianyar, Jembrana, dan Karangasem khususnya Desa Sidemen.

Usaha tenun sudah mulai diminati banyak kalangan di Indonesia khususnya di Bali Kecamatan Sidemen. Hal ini mengakibatkan munculnya banyak persangain antar pengusaha. Dari persaingan yang sulit itu, perusahaan harus menggunakan dan menerapkan strategi manajemen analisis keuangan yang baik dalam mewujudkan tujuan perusahaan dengan menentukan bagaimana produk yang dihasilkan dapat diserap oleh pasar, baik jangka pendek maupun jangka panjang. Selain strategi yang baik, harga jual produk juga berpengaruh terhadap keberlangsungan perusahaan. Harga jual yang tidak sesuai dengan tingkat ekonomi konsumen, maka produk yang diproduksi tidak akan berkembang. Dalam hal ini, perusahaan harus cermat menentukan harga pokok produksi guna menetapkan harga jual produk yang dihasilkan. (Mulyadi, 2009).

Banyak pengusaha kecil menengah tidak memahami bahkan mengetahui cara menghitung harga pokok produksi untuk produk yang dihasilkan dan melakukan perhitungan dengan kaidah metode harga pokok produksi yang baku. Perhitungan biaya-biaya yang berpengaruh terhadap harga pokok produk tidak dicatat dan dihitung, seperti perhitungan biaya penyusutan mesin, gedung maupun peralatan pabrik biaya penyusutan tersebut penting dihitung meskipun nilainya kecil. Hal ini dapat memengaruhi pendapatan yang didapatkan perusahaan.

Dalam menghitung harga pokok terdapat tiga unsur biaya yaitu biaya bahan baku, biaya tenaga kerja langsung, dan biaya overhead pabrik. Biaya produksi ini merupakan unsur biaya yang besar jumlahnya dibandingkan dengan jumlah biaya keseluruhan. Perlu diketahui bahwa efisiensi produksi sangat erat kaitannya dengan biaya produksi. Selain itu, biaya produksi merupakan unsur biaya yang sangat penting dalam menentukan harga pokok produksi. Dalam menentukan harga pokok produksi terdapat metode harga pokok produksi yaitu metode harga pokok produksi berdasarkan pesanan, metode harga pokok berdasarkan proses, Metode Activity Based Costing (ABC), Metode Full Costing dan Metode Variable Costing. (Mulyadi, 2009).

Pengusaha kain endek sutra warna alam tersebut sebagian besar tidak memahami bahkan tidak mengetahui cara untuk menghitung harga pokok produksi untuk produk yang dihasilkan dan melakukan perhitungan dengan kaidah metode harga pokok produksi yang baku. Perhitungan biaya-biaya yang berpengaruh terhadap harga pokok produk tidak dicatat dan dihitung, seperti perhitungan biaya penyusutan mesin, gedung maupun peralatan pabrik.

Dalam penelitian ini, peneliti menggunakan teknik analisis data dengan metode deskriftif analitis. Dari hasil analisis diketahui bahwa perusahaan menghitung dengan menjumlahkan semua biaya yang terkait dalam proses pengiriman paket menuju Negara lain. Harga pokok jasa yang dihasilkan dari perhitungan yang dilakukan oleh perusahaan lebih besar dibandingkan dengan yang dihitung dalam penelitian, sehingga tarif yang dihasilkan pun lebih tinggi.

Penelitian Melly Kusumawardhani (2008) mengenai Analisis Penetapan Harga Pokok Produksi Bibit Krisan pada PT. Inggu Laut Abadi Kabupaten Cianjur, Jawa Barat menyatakan hasil perhitungan yang dilakukan, diketahui adanya perbedaan harga pokok antara metode perusahaan dengan perhitungan harga pokok metode full costing maupun variable costing, baik sebelum maupun sesudah kenaikan harga bahan kimia makro dan mikro. Selain itu Latib Suprihatin (2009) Pada Pabrik Tahu "Bu Gito" Pedan 
dengan Metode process Costing Pada Pabrik Tahu "Bu Gito" Pedan menyatakan analisis data yang digunakan dalam penelitian ini telah melakukan pengumpulan dan perhitungan unsur-unsur biaya produksi yang digunakan sebagai dasar dalam menghitung biaya produksi tahu per blabak pada tiap periode produksinya.

Predana Setiadi (2014) Perhitungan Harga Pokok Produksi Dalam Penentuan Harga Jual pada CV. Minahasa Mantap Perkasa menggunakan metode analisis data dalam penelitian laporan ini. Pengumpulan biaya produksi dilakukan dengan metode harga pokok proses dengan pendekatan full costing, tujuannya untuk memenuhi persediaan di gudang dan jumlahnya sama dari waktu ke waktu. Proses pembuatan roti akan selalu dilakukan adalah analisis data deskriptif dan dengan metode kualitatif dan kuantitatif. Pengumpulan biaya produksi dilakukan dengan metode harga pokok proses dengan pendekatan full costing, tujuannya untuk memenuhi persediaan digudang, dan jumlahnya sama dari waktu ke waktu. Proses pembuatan roti akan selalu dilakukan perusahaan tanpa menunggu ada atau tidaknya pesanan dari pelanggan. Walaupun demikian, bukan berarti perusahaan mengabaikan permintaaan atau keninginan konsumen. Hal ini disebabkan oleh, banyaknya jumlah roti yang diproduksi atau dihasilkan tergantung pada permintaan konsumen serta situasi dan kondisi pada saat itu.

Ade Lutfia Nugraha Heni (2015) Analisis perhitungan Harga Pokok Produksi menggunakan metode Job Order Costing untuk menentukan harga jual pada kerajinan tenun ikat (ATBM) Medali Mas Kediri Dalam penelitian ini peneliti menggunakan penelitian kuantitatif yaitu menggunakan metode expost facto karena peneliti peristiwa yang sudah terjadi dan menganalisis perhitungan yang di lakukan perusahaan dengan menggunakan metode Job Order Costing. Berdasarkan analisis data dalam menghitung harga pokok produksi (HPP) menggunakan metode job order costing dalam menentukan harga jual terdapat selisih lebih antara harga jual yang ditetapkan oleh perusahaan.

Berdasarkan analisis situasi dan kondisi empirik di atas, maka permasalahan yang dialami oleh kurangnya pengetahuan tentang harga pokok produksi ini yang menyebabkan para pengusaha tenun ikat belum bisa menentukan harga pokok produksi dengan benar. Perusahaan tenun ikat mentukan harga pokok produk kain endek sutra warna alam ini bergantung pada biaya produksi dan nonproduksi yang di keluarkan. Dalam hal ini, biaya merupakan dasar dalam penentuan harga, sebab suatu tingkat harga yang tidak dapat menutup biaya akan mengakibatkan kerugian. Melalui pelatihan dan pendampingan ini diharapkan para pengusaha kain tenun ikat ndek dapat membuat harga pokok produksi (cost of goods sold). Pengusaha dapat menentukan harga jual produk sehingga dapat diketahui laba rugi usaha yang dilakukan, yang kemudian dapat dijadikan sebagai pedoman dalam mengambil keputusan bisnis yang berkaitan dengan modal awal, biaya produksi, biaya finising, menentukan harga jual yang sesuai dengan biaya produksi.

Berdasarkan tujuan program pengabdian masyarakat di atas, maka secara realistik implementasi pelatihan dan pendampingan para pengusaha kain tenun ikat ndek di kecamatan Sidemen Kabupaten Karangasem dalam menghitung dan menyusun harga pokok produksi (cost of goods sold) untuk menentukan harga jual produk diharapkan dapat bermanfaat bagi : (1) para pengusaha tenun ikat ndek, pelatihan dan pendampingan dalam menghitung dan menyusun harga pokok produksi (cost of goods sold) untuk menentukan harga jual produk dan (2) para karyawan, dengan adanya sistem penghitungan harga pokok produksi, maka semua modal usaha dan harga jual dapat terhitung dengan baik.

Khalayak sasaran strategis dalam kegiatan ini adalah para pengusaha kain tenun ikat ndek di kecamatan Sidemen Kabupaten Karangasem. Pertumbuhan sektor kerajinan (industri kreatif) di Kabupaten Karangasem juga sangat tinggi jika dibandingkan dengan Kabupaten lainnya di Bali. Selain itu, sebagian besar pelaku usaha belum menerapkan penghitungan harga pokok produksi yang baik dan benar sehingga mereka seringkali mengalami kesulitan dalam menentukan harga jual dan pengambilan keputusan bisnis. Sedangkan informasi akuntansi atau keuangan merupakan syarat penting yang harus dimiliki dan diketahui oleh para pengambil keputusan (pelaku bisnis / stakeholders). Berikut ini adalah peta lokasi pelaksanaan program pengabdian masyarakat:

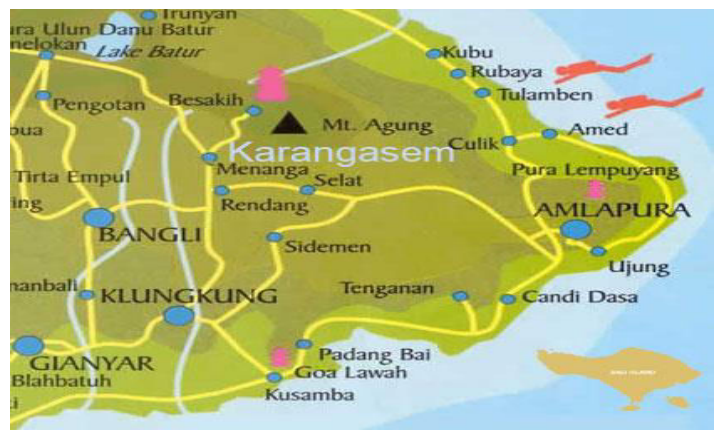




\section{Metode}

Gambar 1. Peta Desa Sidemen Kecamatan Sidemen Kabupaten Karangasem.

Sesuai dengan fokus masalah dan tujuan kegiatan ini, maka metode yang digunakan adalah metode pelatihan dan pendampingan, sehingga untuk melatih pelaku usaha kain tenun ikat ndek, akan dilakukan program pelatihan dan pendampingan secara terjadwal. Setelah dianggap mahir, maka tim pelaksana akan melanjutkan pendampingan pada kelompok usaha dengan prosedur yang sama. Lama pelaksanaan kegiatan adalah 6 (enam) bulan yang dimulai dari tahap pengajuan proposal, perencanaan, pelaksanaan sampai pada evaluasi. Pada akhir program setiap peserta akan diberikan sertifikat sebagai tanda bukti partisipasi mereka dalam kegiatan ini.

Adapun materi yang diberikan selama pelatihan meliputi : (1) pentingnya pembukuan dan keuntungan penggunaannya dalam menjalankan usaha, (2) cara menghitung harga pokok produksi untuk produk yang dihasilkan dan melakukan perhitungan dengan kaidah metode harga pokok produksi yang baku untuk menentukan harga jual produk, (3) informasi biaya yang diperlukan dalam pengendalian biaya produksi untuk menciptakan efisiensi dan efektivitas produk.

Untuk mengukur tingkat keberhasilan kegiatan yang telah dilakukan, maka akan dilakukan evaluasi proses, evaluasi akhir, dan evaluasi tindak lanjut. Keterangan kegaitan evaluasi terdapat pada tabel 1 dibawah ini.

$\underline{\text { Tabel 1. Keterangan kegiatan evaluasi }}$

\begin{tabular}{|c|c|c|c|}
\hline No & Jenis Data & Indikator & Kriteria Keberhasilan \\
\hline 1. & $\begin{array}{l}\text { Penghitungan harga pokok } \\
\text { produksi dan penentuan harga jual }\end{array}$ & $\begin{array}{l}\text { Pengetahuan dan } \\
\text { keterampilan }\end{array}$ & $\begin{array}{l}\text { Terjadi perubahan yang } \\
\text { positif terhadap } \\
\text { pengetahuan dan } \\
\text { keterampilan pelaku usaha } \\
\text { kain tenun ikat ndek }\end{array}$ \\
\hline 2. & $\begin{array}{l}\text { Penghitungan HPP dan penentuan } \\
\text { harga jual sesuai dengan yang } \\
\text { dilatih }\end{array}$ & Keterampilan & $\begin{array}{l}\text { Terjadinya perubahan yang } \\
\text { positif terhadap } \\
\text { keterampilan pelaku usaha } \\
\text { kain tenun ikat ndek }\end{array}$ \\
\hline 3. & $\begin{array}{l}\text { Menggunakan penghitungan HPP } \\
\text { dan penentuan harga jual dalam } \\
\text { usaha }\end{array}$ & $\begin{array}{l}\text { Pengetahuan dan } \\
\text { keterampilan }\end{array}$ & $\begin{array}{l}\text { Terjadinya perubahan } \\
\text { kemampuan dan } \\
\text { keterampilan pada pelaku } \\
\text { usaha kain tenun ikat ndek }\end{array}$ \\
\hline
\end{tabular}

\section{Hasil dan pembahasan}

Melalui pelatihan dan pendampingan ini diharapkan para perajin dapat (1) membuat pembukuan dan keuntungan penggunaannya dalam menjalankan usaha, (2) menghitung harga pokok produksi untuk produk yang dihasilkan dan melakukan perhitungan dengan kaidah metode harga pokok produksi yang baku untuk menentukan harga jual produk, dan (3) mengetahui informasi biaya yang diperlukan dalam pengendalian biaya produksi untuk menciptakan efisiensi dan efektifitas produk. Jika dilihat dari fenomena yang ada maka sebagian besar pengerajin belum memiliki kualitas sumber daya manusia yang memadai dalam pengelolaan keuangan. Jika dilihat secara teoretis, pembukuan merupakan proses pencatatan yang dilakukan secara teratur untuk mengumpulkan data dan informasi keuangan suatu perusahaan atau organisasi. Pencatatan itu meliputi harta, kewajiban, modal, penghasilan dan biaya, serta jumlah harga perolehan dan penyerahan barang atau jasa, yang ditutup dengan menyusun laporan keuangan berupa neraca, dan laporan laba rugi untuk periode tahun fiskal tersebut. Pembukuan dapat digunakan sebagai alat kontrol keuangan usaha. Kita dapat mengetahui biaya-biaya mana yang tidak perlu, biaya mana yang merupakan pemborosan (inefisiensi). Dengan demikian biaya tersebut dipotong dan akan mengefisienkan usaha dengan lebih baik. Tanpa adanya pembukuan, hal tersebut tidak akan mungkin bisa dilakukan karena secara nyata angka itu tidak pernah tercatat.

Dengan melakukan pembukuan berarti kita sudah berperan sebagai warga negara yang baik, yaitu dengan melaporkan pajak hasil usaha yang dilakukan. Perhitungan pajak didasarkan pada laporan keuangan usaha yaitu dari neraca dan laporan laga rugi. Pembukuan usaha, yang nantinya berakhir ke dalam bentuk laporan keuangan dapat digunakan sebagai dasar, layak tidaknya usaha tersebut jika menerima tambahan modal dari pihak lain seperti investor, pihak perbankan, dan perusahaan ventura. 
Dasar laporan keuangan ini merupakan ketentuan wajib bagi lembaga keuangan untuk berinvestasi di perusahaan tersebut karena laporan keuangan ini menunjukkan baik tidaknya kondisi perusahaan, dilihat dari untung-rugi, efisien-boros, dan pengelolaan aset usaha.

Kendala-kendala yang dihadapi oleh perajin dalam pengelolaan keuangan di Kecamatan Sidemen Kabupaten Karangasem, yaitu (1) kurangnya sumber daya manusia yang ada dalam pengelolaan keuangan usaha, dimana rata-rata memiliki pemahaman yang kurang mengenai penyusunan laporan keuangan dan kurangnya pemahaman mengenai aturan-aturan yang ada, (2) sumber daya manusia yang menangani hanya satu orang saja dan belum memahami mengenai teknik penghitungan pajak usahanya, (3) beberapa bukti transaksi yang diterima belum lengkap, dan (4) kurangnya pemahaman pengelola keuangan terutama penghitungan biaya-biaya produksi.

Setelah diberikan pelatihan dan pendampingan kepada para pengerajin dalam pengelolaan keuangan di Kecamatan Sidemen Kabupaten Karangasem mengakui mereka memiliki kemampuan dan keterampilan yang memadai dalam membuat pertanggungjawaban yang digunakan untuk menghitung aliran masuk dan keluarnya dana. Adapun hasil dari kegiatan pengerajin dalam penyusunan laporan harga pokok produksi di Kecamatan Sidemen Kabupaten Karangasem, yaitu: sebagian besar para pengerajin dapat: (1) membuat pembukuan dan keuntungan penggunaannya dalam menjalankan usaha, (2) menghitung harga pokok produksi untuk produk yang dihasilkan dan melakukan perhitungan dengan kaidah metode harga pokok produksi yang baku untuk menentukan harga jual produk, dan (3) mengetahui dan memahami informasi biaya yang diperlukan dalam pengendalian biaya produksi untuk menciptakan efisiensi dan efektivitas produk.

\section{Simpulan dan saran}

Pelatihan dan Pendampingan kegiatan P2M tersebut dilakukan pada bulan Juni di Kecamatan Sidemen Kabupaten Karangasem. Alur pelatihan pengelolaan keuangan desa dimulai dari: (a) penyiapan bahan administrasi sesuai dengan kebutuhan pelaksanaan pelatihan, (b) melakukan koordinasi dengan para pengerajin di Kecamatan Sidemen Kabupaten Karangasem, (c) menyiapkan materi pelatihan, (d) menyiapkan narasumber yang memiliki kompetensi sesuai dengan target dan tujuan pelatihan. Hasil melalui kegiatan dalam penyusunan laporan harga pokok produksi di Kecamatan Sidemen, Kabupaten Karangsem, sebagian besar perajin telah berhasil (1) membuat pembukuan dan keuntungan penggunaannya dalam menjalankan usaha, (2) menghitung harga pokok produksi untuk produk yang dihasilkan dan melakukan perhitungan dengan kaidah metode harga pokok produksi yang baku untuk menentukan harga jual produk, dan (3) mengetahui dan memahami informasi biaya yang diperlukan dalam pengendalian biaya produksi untuk menciptakan efisiensi dan efektivitas produk.

Beberapa hal yang bisa dijadikan rekomendasi dari pelaksanaan pengabdian pada masyarakat ini adalah sebagai berikut. (1) Kurangnya sumber daya manusia yang ada dalam pengelolaan keuangan usaha, dimana rata-rata memiliki pemahaman yang kurang mengenai penyusunan laporan keuangan dan kurangnya pemahaman mengenai aturan-aturan yang ada, sehingga perlunya ada pembinaan dari dinasdinas terkait serta memberikan pelatihan terkait manajemen usahanya, (2) beberapa bukti transaksi yang diterima belum lengkap dalam menyusun pembukuan agar mulai dibenahi, dan (3) para perajin agar meningkatkan lagi kemampuannya dalam pengelolaan keuangan dan pembukuan

\section{Daftar Rujukan}

Ade Lutfia Nugraha Heni. (2015). “Analisis perhitungan Harga Pokok Produksi menggunakan metode Job Order Costing untuk menentukan harga jual pada kerajinan tenun ikat (ATBM) Medali Mas Kediri"

Baridwan, Zaki.2010. Intermediate Accounting. Yogyakarta: BPFE.

Bastian Bustami dan Nurela. 2009. Akuntansi Biaya, salemba empat.

Dewi Kasita Rachmayanti. (2011). "Analisis Perhitungan Harga Pokok Produksi Sepatu Dengan Metode Full Costing (Studi Kasus: Ukm Galaksi Kampung Kabandungan Ciapus Bogor)". tersedia pada http://repository.ipb.ac.id/bitsteam/handle/123456789/4767/H11dkr.pdf?sequence=1 (diakses tanggal (20 September 2016).

Hanggana. 2009. Prinsip Dasar Akuntansi Biaya. Surakarta:Media Utama. 
Hansen, and Mowen. 2009. Manajemen Biaya, edisi 2, buku 1 diterjemahkan oleh Dewi Fitriasari dan Deny Arnos Kwary, thomson learning. Jakarta :Salemba empat.

Kholomi dan Yuningsih. 2009, Akuntansi Biaya untuk Perhitungan Biaya Pokok Produksi. (Sistem Biaya Historis). Yogyakarta : BPFE-UGM.

Latib Suprihatin. 2009. "Penyusunan Harga Pokok Produksi Pada Pabrik Tahu "Bu Gito" Pedan Dengan Metode Process Costing". Tersedia pada http://eprints.uns.ac.id/9975/1/105762010200908011.pdf. (diakses tanggal 20 September 2016).

Melly Kusumawardhani. 2008. “ Analisis Penetapan Harga Pokok Produksi Bibit Krisan pada PT. Inggu Laut Abadi Kabupaten Cianjur, Jawa Barat".http://repository.ipb.ac.id/bitstream/handle/123456789/2369/A08mku.pdf?sequence=5 (diakses tanggal 20 september 2016).

Mulyadi. 1999. Akuntansi Manajerial. Yogyakarta: Aditya Medika

-----. 2001. Sistem Akuntansi , Edisi Ketiga. Yogyakarta: Salemba Empat

-----2003.Activity Based Cost System.Yogyakarta:UPP AMD YKPN

-----.2006. Activity Based Cost System. Jakarta: Salemba Empat

Mulyadi. 2007. Akuntansi Biaya. Yogyakarta:BPFE-UGM.

Mulyadi. 2009. Akuntansi biaya. Edisi kelima.Yogyakarta. Universitas Gadjah Mada

Mulyadi, 2010, Akuntansi Biaya, Yogyakarta : BPFE UGM.

Mulyadi.2010, Akuntansi Manajemen Konsep, Manfaat \& Rekayasa.Edisi 3. Jakarta: Salemba Empat.

Moh. Yusuf Wibisono. 2015, Analisis Penentuan Harga Pokok Produksi Berdasarkan Sistem Activity Based Costing Pada UD. Katon Ragil

Rahany. 2003. "penetapan harga pokok produksi kecap dan pendekatan Activity Based Costing (ABC) di PT Surabraja Food Industry Cirebon, Jawa Barat". Tersedia pada http://repository.ipb.ac.id. (Diakses pada tanggal 20 September 2016).

Risma Catharin Rahmawaty Sirait. 2006. “Analisa Perhitungan Harga Pokok Produksi dan Penentuan Harga Jual Coca Cola Pada PT.Coca Cola" Tersedia pada http://repository.usu.ac.id/handle/123456789/9248 (Diakses tanggal 20 September 2016).

Swastha, Basu dan Irawan, 2005, Menejemen Pemasaran Modern, Yogyakarta : Liberty.

Verina H. Secapramana, 2001. "Model Dalam Strategi Penetapan Harga". Tersedia pada http://repository.ubaya.ac.id/45/1/ART003.pdf (di akses pada tanggal 18 april 2014).

Wati Aris Astuti \& Gyan Herliana. 2011. "Analisis Perhitungan Harga Pokok Jasa Pengiriman Untuk Penetapan Tarif Pengiriman Paket Internasional (Tujuan Jepang) Di Pt Pos Indonesia Tahun 2011" tersedia pada http://jurnal.unikom.ac.id/_s/data/jurnal/volume-11-1/03-miu-11-1 wati.pdf/pdf/03-miu-11-1-wati.pdf. (diakses pada tanggal 20 September 2016). 